\title{
SERVICES CONFERENCE AS AN ANSWER TO CHALLENGES OF ADMINISTRATIVE PROCEDURE ${ }^{1}$
}

\author{
Robert Siuciński \\ University of Łódź, Faculty of Law and Administration
}

\begin{abstract}
The paper presents the services conference as one of the forms of conducting administrative proceedings. The starting point is to present an institution shaped in the Italian procedural law in the light of its administrative system and its evolutionary transformations. The paper involves a comprehensive analysis of the services conference in the context of the competence of public administration authorities, the procedural guarantees enjoyed by parties to the proceedings and decisions that may be taken in the course of the services conference, as well as the legal possibility of their change. One of the assumptions of the paper is the possibility of recognition of the services conference as a kind of a resultant of proceedings in a form of hearing, and the mode of co-operation between the bodies. As a result, it should lead to presenting prospects and opportunities to adapt the institution of the services conference in the Central European countries also as a future solution for the Slovak Code of Administrative Procedure.
\end{abstract}

Key words: administrative procedure, services conference, convergence

\section{INTRODUCTION}

The aim of the article is to present the services conference as one of the forms of conducting administrative proceedings. The starting point is to present an institution shaped in the Italian procedural law in the light of its administrative system and its evolutionary transformations. It will require a discussion of the origin and functioning of the Law of 7 August 1990, n. 241 - New rules concerning administrative proceedings and the right of access to administrative documents (Nuove norme in materia di procedimento amministrativo e diritto di accesso ai documenti amministrativi), ${ }^{2}$ and in particular its numerous amendments dictated by the needs to simplify, streamline and modernize the law. The paper involves a comprehensive analysis of the services conference in the context of the competence of public administration authorities, the procedural guarantees enjoyed by parties to the proceedings and decisions that may be taken in the course of the services conference, as well as the legal possibility of their challenge.

To understand the concept and importance of the services conference, it will be distinguished from the structure of cooperation of public administration authorities by presenting European solutions in this area. The analysis of form and the legal nature of "taking position by the cooperating body", evidence proceedings before a co-operative body, the control of acts of cooperation

1 The project was financed by the National Science Centre, Poland in the framework of the research grant no. 2016/21/N/ HS5/02029.

2 Gazzetta Ufficiale of 18 August 1990, no. 192. 
and the confrontation of these findings with decision-making in accordance with the provisions of the services conference need special attention. A distinction between the services conference and administrative procedure in the form of a hearing is also important. It will require a comparative analysis, including primarily the need to confront with the oral hearing (mündliche Verhandlung) well-known to the members of the German legal culture (Austria, Germany) and hearing practiced in common law systems.

Moreover, the aim of the article is to introduce the Italian experience as adopted by new Portuguese Code of Administrative Procedure of January 7, 2015 (Codigo de procedimento administrativo). ${ }^{3}$ It is clearly indicated in the preamble to the act that the inspiration to take a legislative initiative was the implementation of a number of new solutions to the Portuguese administrative proceedings, mainly the institutions of the processual conference (conferencia procedimental), adjusting the duty of good management (boa gestao), provisions on liability for breach of terms and codes of good practice (codigos de conduta). The article will address the issue of implementation of modern trends to the Portuguese procedural law after the use of comprehensive comparative analysis, including the achievements of the Italian, Spanish, German and European Union law. From that point of view the study can also verify the hypothesis of progressive convergence of administrative law, not only in the plane of the "top-down" unification (globalization, Europeanization), but also through "grassroots" initiatives associated with the mutual exchange of the most effective solutions between different systems.

To present the institution as a specific expression of concentration of evidence and coordination of public administration and the establishment of extensive comparative research can be considered as pioneering. The research problem is the most current, and the achievement of the intended objective of the paper can exert an impact on the development of the discipline of administrative law. New function of comparative law involves to identify trends and patterns with a view to respond to these. Auxiliarily, a historical method will also be used, because law is a social phenomenon of a dynamic nature.

\section{SERVICES CONFERENCE AS A FORM OF ADMINISTRATIVE PROCEEDINGS}

\subsection{Services conference in Italian administrative law}

\subsubsection{History and legal nature of the institution}

In Central European literature lack any articles contributing to the development of the institution of the services conference. Furthermore, an institution of the services conference did not actually go through a thorough, comprehensive discussion outside the Italian and Portuguese literature, despite the fact that research into various types of legal forms of cooperation between authorities and coordination of their functioning in the framework of the so-called administrative networks are currently being conducted in Europe and in the world. From that point of view, the presentation of the genesis and evolution of the Italian system of proceedings before public administration authorities, the basic principles of the Law of 7 August 1990, n. 241 - New rules concerning administra-

3 Approved by the Decree-Law no. 4/2015 of 7 January 2015 (Decreto-Lei $n^{\circ}$ 4/2015, de 7 de janeiro), Diário da República, 1.a série-N.o $4-7$ de janeiro de 2015. 
tive proceedings and the right of access to administrative documents, the idea of simplifying and informalisation guiding subsequent amendments of this Act and a services conference attempting to answer to the ills of the Italian public administration, have crucial importance. The services conference should be presented on the background of the Italian system of administrative procedure, because only such approach will allow for a full understanding of its specificity. The history of the formation of this institution, the most significant modifications of its construction, the reasons for their implementation, an explanation of the related terminology and its reconstruction in the science of law and jurisprudence will be indicated.

Since the late fifties of the twentieth century in Italy, the first doctrinal reflections concerning the development of the institution of the services conference in the administrative practice have been emerging. ${ }^{4}$ In that period concepts describing its legal nature have begun to emerge: as an instrument of unstructured cooperation (collaborazione non organica), an administrative consortium (consorzio amministrativo) or inter-ministerial committee (comitato interministeriale). It is now possible to draw at least three main theoretical reconstructions that shape the conference as an instrument related to the conclusion of a contract between public administrations, as a separate authority - independent in relation to other individual participants or as a simple procedural form. ${ }^{5}$

\subsubsection{Types of services conference}

We must focus on the functioning of the institution of the services conference in the Italian administrative proceedings and impact of the conference on the competences of the bodies taking part in it, as well as on the procedural guarantees for the parties and other participants in the proceedings, during which the conference is carried out and the individual and collective interests, that can be represented on it. This will allow discussion about the types of decisions taken at the services conference, including ways of overcoming the situation associated with the inertia of public administrations, understood as the silence of the administration, the lack of a decision within the time limit, the absence of consent of cooperating body, or other forms of unjustified prolongation of the proceedings or the stalling of time to take a final settlement.

A relatively simple typology scheme of the services conference is reduced by a part of the doctrine to a single model. However, the analysis of the moves of the Italian legislator requires to adopt a more complex typology. ${ }^{6}$ The legislator, despite introducing more than twenty amendments relating to the services conference, did not negate their differentiation. It is also reflected in the jurisprudence of the Italian administrative courts and the Council of State (Consiglio di Stato). ${ }^{7}$ According to the most common division we have: explanatory conference (la conferenza istruttoria), decisionmaking conference (la conferenza decisoria) and predecision-making (la conferenza predecisoria). Moreover, according to the structural criterion we can divide them into internal decision-making and predecision-making conferences (la conferenza decisoria / istruttoria interna) and external ones (la conferenza decisoria / istruttoria esterna). Another scheme involves the division according to the

4 TALANI, M. La conferenza di servizi. Nuovi ordinamenti giurisprudenziali. Milan : Giuffrè, 2008, p. 5, MUSONE, R. La conferenza di servizi in materia ambientale. Rome : Aracne, 2013, p. 13 - 14 and D'ORSOGNA, D. Conferenza di servizi e amministrazione della complessità. Turin : Giappichelli, 2002, p. 68. It should be mentioned that the last author indicates also one example from the law no. 1822 of 1939.

5 MUSONE, R. La conferenza di servizi..., op. cit., p. 41. Similarly D’ORSOGNA, D. Conferenza di servizi..., p. 106.

6 MUSONE, R. La conferenza di servizi..., p. 61.

7 D'ORSOGNA, D. Conferenza di servizi..., p. $102-107$. 
criterion of the number of proceedings. There are therefore conferences monoprocedural (la conferenza monoprocedimentale) and pluriprocedural (la conferenza pluriprocedimentale).

The authority conducting the procedure may call a services conference when the joint consideration of several public interests involved in an administrative procedure should be appropriate. A services conference may also be convened for the joint consideration of interests involved in several connected administrative procedures regarding the same activities or results. In such a case, the conference shall be called by the authority or, after reaching an informal understanding, by one of the authorities that are responsible for the prevalent public interest. The calling of a conference may be requested by any of the other authorities involved. In this case we are dealing with conferenza istruttoria. $^{9}$

Another type is conferenza decisoria, which shall always be called when the authority conducting the procedure has to acquire understandings, agreements, permissions or assent documents of whatever denomination from other public authorities and does not obtain them within thirty days of the competent authority's receipt of the related request. That kind of conference may likewise be called when, within the same timeframe, dissent has been expressed by one or more of the authorities addressed or in the cases where the authority conducting the procedure is permitted to make provision directly in the absence of determinations by the authorities with competence. When the activity of a private party is subject to the formal consent, howsoever defined, of more than one public authority, a services conference shall be convened, including at the request of the interested party, by the authority with competence to adopt the final measure. ${ }^{10}$

Unlike the preceding types, conferenza predecisoria may be convened at the request of the interested party before the presentation of a definitive application or project for particularly complex projects or projects concerning installations producing goods or services. The request must contain a statement of reasons and, in the absence of a preliminary project, be documented by a feasibility study. The conference shall have the purpose of examining on what conditions the necessary formal consent may be obtained when the definitive application or project is presented. In such cases, the conference shall state its conclusions within thirty days of the date of the request and the related costs shall be borne by the party making the request. In procedures concerning the realisation of public works or works in the public interest, the services conference shall evaluate the preliminary project for the purposes of indicating the conditions under which the understandings, opinions, concessions, authorizations, licences, permissions or assent documents of whatever denomination required by the legislation in force for the definitive project may be obtained. On that occasion, the authorities responsible for protection of the environment, the landscape and territory and the historical and artistic heritage or protection of health and public safety shall assess the project's proposed solutions with reference to the interest that each one protects. If, on the basis of the available documentation, no elements definitively precluding the project's realisation emerge, the aforesaid authorities shall, within forty-five days, indicate the conditions and elements necessary for obtaining formal consent when the definitive project is presented. ${ }^{11}$ In that case, the officer with exclusive responsibility for the procedure shall send the authorities concerned a copy of the definitive project, drawn up on the basis of the conditions indicated by the same authorities during the services con-

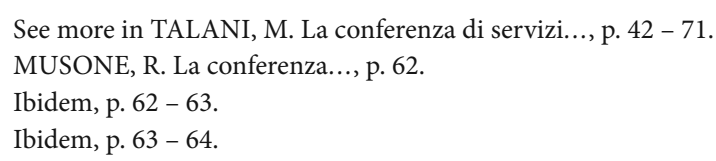


ference on the preliminary project. He/she shall convene the conference on a date falling between the thirtieth and sixtieth day following the project's transmission. In cases where public works are entrusted by way of a procurement contract, competitive tendering or the grant of a licence, the contracting authority shall convene the services conference on the sole basis of the preliminary project. The services conference shall express its view on the basis of the documents at its disposal and the indications given on that occasion may be modified or integrated only if significant elements emerge during subsequent phases of the procedure, including following observations made by private parties in relation to the definitive project. Such modifications or integrations must include a statement of reasons.

\subsubsection{Functioning of services conference}

The first meeting of the conference shall be convened within fifteen days or, in cases where the preliminary fact-finding activities are particularly complex, within thirty days of the date on which it was called. The services conference shall take decisions concerning the organization of its work by way of a majority of those present and may be conducted electronically. The communication convening the first meeting must reach the public authorities concerned (including by electronic or computerised means) at least five days before the relevant date. Should they be unable to participate, the authorities convened may, within the next five days, request that the meeting be held on another date; in such case, the authority conducting the procedure shall arrange a new date, within ten days of the first, in any case. The new date for the meeting may be fixed within the following fifteen days in cases where the request is made by an authority responsible for cultural heritage. The officers responsible for the single offices covering productive activities and building ( $i$ responsabili degli sportelli unici per le attività produttive e per l'edilizia), where established, or the municipalities shall agree with the superintendents having territorial competence on the programme (lasting at least three months) for those meetings of the services conferences that involve the formal assent or advisory papers of whatever denomination falling within the competence of the Ministry of Cultural Assets and Activities. ${ }^{12}$

During the first meeting of the services conference or, in any event, during that immediately following transmission of the application or the definitive project, the authorities participating in it shall determine the timeframe for adopting the final decision. The conference proceedings shall not exceed ninety days (with some exceptions). Upon expiry of such timeframe without result, the authority conducting the procedure shall take action when every authority that has been convened shall participate in the services conference through a sole representative, which shall have the competent organ's authorisation to express the authority's will bindingly in relation to all the decisions falling within the latter's competence. Clarifications or further documentation may be requested only once from the application's proponents or the design engineers during the services conference. If the clarifications or further documentation are not supplied to the conference within thirty days of the request, the conference shall proceed to consider the final measure to be adopted. ${ }^{13}$

The parties proposing the project to be discussed at the services conference shall be summoned to the services conference and shall participate in it without voting rights. The licensees and public service providers may participate, without voting rights, in the conference in those cases where the administrative procedure or the project to be discussed at the conference implies duties for them or

12 D'ORSOGNA, D. Conferenza..., p. $188-198$.

13 D'ORSOGNA, D. Conferenza..., p. $207-213$. 
affects their activities directly or indirectly. Communication of the services conference's convocation shall be sent to the same, including electronically and suitably in advance. The authorities responsible for managing any existing public incentive may also participate in the conference without voting rights. ${ }^{14}$ The parties should participate in the services conference on the basis of the chapter III of the Italian law on administrative procedure (law no. 241 of 1990). From the parties' point of view especially important is the article 7 of that law, according to which if there exist no impediments deriving from the need to conduct a procedure particularly swiftly, the commencement of a procedure shall be communicated, using the methods provided for by article 8 , to the parties who will be directly affected by the final measure and to those who are required by law to intervene. Likewise, provided there exists none of the aforesaid impediments, should a measure be capable of adversely affecting identified or easily identifiable parties other than its direct addressees, the authority shall have the duty to inform them, using the same methods, of the beginning of the procedure. ${ }^{15}$

Analysis of the Italian services conference must be combined with the analysis of the concepts related to the rationalization (razionalizzazione), effectiveness (efficacia) and efficiency (efficienza) of administrative activities. The provisions concerning that institution are placed in the chapter IV of the law of administrative procedure entitled simplification of the administrative action. There is no doubt that the intention of the legislator was to make from the services conference one of the main remedies to fulfil the simplification of administrative procedure. In the operating conferences, routine decisions are replaced by the complex decisions. Because of the blurring of the difference between the main and secondary interest, the rule of the exercise of discretion power changes, in order that specific interest be protected. Individual proceedings merge into a single administrative action. A thorough discussion of the indicated types of services conferences is necessary for the presentation of the opportunity to question its results in an administrative or judicial mode.

The dissent of one or more representatives of the authorities duly summoned to a services conference, including those responsible for protection of the environment, ${ }^{16}$ the landscape and territory, the historical and artistic heritage or the protection of health and public safety, must, on pain of inadmissibility, be expressed during the services conference, must include an appropriate statement of reasons, cannot refer to related issues that do not constitute the subject-matter of the same conference and must specifically indicate the amendments to the project that are necessary in order to obtain assent. ${ }^{17}$

\subsection{Services conference and other forms of administrative proceedings}

Now to present the distinction between services conference, cooperation between administrations and proceedings in the form of hearings, I will use comparative method involving the analysis of

14 TALANI, M. La conferenza..., 71 - 77 and D’ORSOGNA, D. Conferenza..., p. 133 - 137.

15 The article 8 of the Italian law no. 241/1990 states that the authorities shall give a notice of a procedure's commencement by way of a personal communication (section 1) and that communication must indicate: the authority with competence, the object of the procedure commenced, the office and the person responsible for the procedure, the date by which the procedure must be concluded and the remedies available, in the case of the authority's failure to act, in procedures initiated by an interested party, the date on which the related application was presented and the office at which the documents may be inspected (section 2).

16 Without prejudice to the provisions of article 26 of Decreto legislativo no. 152 of 3 April 2006 (Norme in materia ambientale), Gazzetta Ufficiale no. 88 of 14 April 2006, Supplemento Ordinario no. 96.

17 See more in D'ORSOGNA, D. Conferenza di servizi..., p. 230 - 237. 
the cooperation and other similar solutions, as well as oral hearings in different jurisdictions. Preliminary findings have shown considerable diversity in this respect.

\subsubsection{Interadministrative relations}

In administrative procedures of Iberian countries and referring to their achievements, in IberoAmerican countries there are forms such as: coordination (coordinación), cooperation (cooperación) and collaboration (colaboración). New Spanish Law on the Legal Regime of Public Sector ${ }^{18}$ provides as a one of the general principles that the public administrations must respect in their own activities and relations principles of cooperation, collaboration and coordination (article 3 section 1 letter $\mathrm{k}$ ). Title III devoted to the interadministrative relations (relaciones interadministrativas) enumerates these three and in addition electronic relations between administrations. The different public administrations act and relate to other administrations and entities or organizations linked to or dependent on them according to the principles of institutional loyality, adequacy to the distribution of competences established in the Spanish Constitution, in the Statutes of Autonomy (Estatutos de Autonomía) and in the regulations of the local regime, collaboration (understood as the duty to act together with the rest of Public Administrations for the achievement of common goals), cooperation (when two or more public administrations, voluntarily and in the exercise of their powers, assume specific commitments for the sake of common action), coordination (under which a public administration and, in particular, the general state administration, has the obligation to ensure the consistency of the actions of the different public administrations affected by the same subject matter in order to achieve a common result), efficiency in the management of public resources, sharing the use of common resources, unless it is not possible or justified in terms of their best use, responsibility of each public administration in the fulfillment of its obligations and commitments, guarantee and equality in the exercise of the rights of all citizens in their relations with the different administrations and inter-territorial solidarity in accordance with the Constitution (first section of article 140 entitled "principles of interadministrative relations"). ${ }^{19}$

Among the technics of multilateral cooperation is included first of all the creation of the organ of cooperation, which is the so-called conference. In the field of Spanish law we can distinguish two types of that institution: presidential conference (Conferencia de Presidentes) and sectoral conferences (Conferencias Sectorales). First of them is the structure of cooperation between national government and governments of autonomous communities (article 146 of Law on the Legal Regime of Public Sector). The second one is the body of cooperation between the members of national and autonomous communities' government responsible for the same matters (article 147 of Law on the Legal Regime of the Public Sector). Sectoral conferences may exercise consultative function, decision-making or coordination aimed at reaching agreements on common matters so they could be comparable with Italian services conference. However, we must remember that the Spanish institution is still a new organ of administration, not the procedural form of administrative interaction, which can be definitely more flexible (like it is in Italy). We must also take into account that the Spanish administrations cooperate in the service of the general interest (not in

18 Law 40/2015 of 1 October 2015 on the Legal Regime of Public Sector (Ley de Régimen Jurídico del Sector Público), Boletín Oficial del Estado no. 236 of 2 October 2015.

19 COLL COSTA, J. Principios de las relaciones interadministrativas. In RECUERDA GIRELA, M.Á. (ed.). Régimen jurídico del Sector Público y Procedimiento Administrativo Común de las Administraciones Públicas. Pamplona : Aranzadi, 2016, p. $1725-1730$. 
indvidual administrative procedure) and may voluntarily agree on in which form exercise of their respective competences best serves the principle of cooperation (article 143 section 1 of Law on the Legal Regime of Public Sector). The formalization of cooperation relations will require the express acceptance of the parties of that cooperation, formulated in accords of cooperation organs or in agreements (second section of the aforementioned article), therefore it is much more strict and formal that Italian provisions. ${ }^{20}$

Many of the Ibero-American states have approved legal solutions quite similar to Spanish. According to the article 3 of the Colombian Code of Administrative Procedure and Administrative Dispute Procedure, ${ }^{21}$ coordination is one of the principles of procedure. Section 10 of that article states that the public authorities should coordinate their activities with the other authorities in carrying out their duties and recognizing the rights of individuals. As A. R. Brewer-Carías underlines, in comparative law, the principle of coordination (el principio de la coordinación) is traditionally viewed as a rule of the organisation of administration rather than a procedural principle. ${ }^{22}$ The article 4 of the Ecuadorian Decree no. 1634 of 1994 states that all bodies of executive power must act in the general interest of the public and respect, inter alia, principles of cooperation and coordination (los principios de cooperación y coordinación). Among the general principles (principios generales) of the procedure in article 101 the legislator indicated coordination (section 1) and the requirement for public administration bodies to respect the principle of cooperation and collaboration (principio de cooperación y colaboración) in their relations and in their activities, as well as the criteria of efficiency and utility for the citizens (section 2). ${ }^{23}$ Other examples of that kind of institutions can be found in the laws of administrative procedure in Mexico, ${ }^{24}$ Bolivia, ${ }^{25}$ Costa Rica, ${ }^{26}$ Panama, ${ }^{27}$ Peru $^{28}$ and Venezuela. ${ }^{29}$

20 See MANCILLA I MUNTADA, F. Cooperación entre Administraciones Públicas and RECUERDA GIRELA, M.Á. Órganos de cooperación. InRECUERDA GIRELA, M.Á. (ed.). Régimen..., op. cit., respectively p. 1755 - 1762 and p. 1766 1767.

21 Colombian Law no. 1437 of 18 January 2011 (Código de Procedimiento Administrativo y de lo Contencioso Administrativo).

22 BREWER-CARÍAS, A.R. Los principios del procedimiento administrativo en el Código de procedimiento administrativo y de lo contencioso administrativo de Colombia (Ley 1437 de 2011). In RODRÍGUEZ-ARANA MUŃOZ, J., BELARMINO JAIME, J., SENDÍN GARCÍA, M.Á., MEJÍA, H.A., CARDOZA AYALA M.Á., (eds.). Congreso Internacional de Derecho Administrativo. X Foro Iberoamericano de Derecho Administrativo El Salvador 2011. El Salvador : San Salvador, 2011, p. 901.

23 Estatuto del Régimen Jurídico Administrativo de la Función Ejecutiva, Registro Oficial no. 411 of 31 March 1994, second suplement.

24 Federal Law of 14 July 1994 on Administrative Procedure (Ley Federal de Procedimiento Administrativo), Diario Oficial de la Federación of 4 August 1994, article 69-D.

25 Law no. 2341 of 23 April 2002 on Administrative Procedure (Ley $n^{\circ} 2341$ de 23 de abril de 2002, Ley de procedimiento administrativo) as an element of the principle of good faith (buena fe) established in article 4 letter e.

26 General Law no. 6227 of 2 May 1978 on Public Administration (Ley General de la Administración Pública), La Gaceta no. 102 of 30 May 1978, article 100

27 Law no. 38 of 31 July 2000, which approved Organic Statute of the Procuraduría de la Administración, regulate administrative procedure and enacted special provisions (Ley que aprueba el Estatuto Orgánico de la Procuraduría de la Administración, regula el Procedimento Administrativo y dicta disposiciones especiales), article 6 section 2 and 8 , articles 8 and 19.

28 Law no. 27444 on General Administrative Procedure (Ley $N^{\circ} 27.444$ - Ley de Procedimiento Administrativo General), Diario Oficial „El Peruano” of 11 April 2001, especially articles 74.2 and 76 - 79.

29 Organic Law on Administrative Procedures of 1 July 1981 (Ley Orgánica de Procedimientos Administrativos), Gaceta Oficial de la República Bolivariana de Venezuela extraordinary no. 2818, article 40. 


\subsubsection{Hearings in administrative proceedings}

In opinion of D. R. Kijowski, Austrian provisions concerning on the oral hearings contained in $\$ 40-44$ of $\mathrm{AVG}^{30}$ can be treated as a typical. ${ }^{31}$ According to these provisions, all known persons involved as well as all witnesses and experts required shall be called in to oral hearings and, provided that such hearings include a judicial inspection, they shall preferably be held on site, or otherwise at the office of the authority or at such place deemed most feasible in accordance with the situation. In choosing the place for holding the hearing, attention is to be paid that it is accessible for handicapped persons without any danger and without having to resort to help by third persons unless the hearing is combined with a judicial inspection of the premises. In such case, the officer of charge will preside.

That form of administrative proceedings is also accepted in the other countries connected with Austrian (Austro-Hungarian) tradition of administrative law. In the Slovak codification of administrative procedure - Zákon o správnom konaní (správny poriadok) ${ }^{32} \$ 21$ indicates verbal hearing (Ústne pojednávanie). According to this provision, the administrative authority shall order the verbal hearing to be held if the nature of the matter so requires, in particular if it would contribute to clear the matter up or if required by special legislation. If an inspection is to be part of the verbal hearing, it is usually held in the place of inspection. The administrative authority shall invite all the parties asking them to present their comments and make their proposals. Special legislation shall determine the cases in which the comments and objections made subsequently shall not be considered, the participants must be explicitly warned of this fact. Unless otherwise provided by special legislation or by the administrative authority the verbal hearing is closed to public.

In German Federal Administrative Procedure Act (VwVfG) ${ }^{33} \$ 67$ provides requirement for an oral hearing. The authority shall decide, which participants shall be invited in writing on due notice. The invitations should point out that if a participant fails to appear, the discussions can proceed and decisions be taken in his absence. If more than 50 invitations must be sent, this may be done by public announcement. Only in situations enumerated in $\$ 67$ section 2 of VwVfG, the authority may reach a decision without an oral hearing. According to $₫ 68 \mathrm{VwVfG}$ the oral hearing shall not be public. It may be attended by representatives of the supervisory authority and by persons working with the authority for training purposes. The person in charge of the hearing may admit other people only if no participant objects. The person in charge of the hearing shall discuss the matter with the parties concerned. He shall endeavour to clarify applications which are unclear, to see that relevant applications are made, inadequate statements supplemented and that all explanations necessary to ascertain the facts of the case are given. The person in charge is responsible for keeping order. He is also obligated to prepare a written record, which after hearings shall be signed. ${ }^{34}$

That kind of hearings (mündliche Verhandlung, ústne pojednávanie, rozprawa) has many of the characteristics corresponding to the proceedings before the court and this leads us to the conclu-

30 General Administrative Procedure Act of 21 July 1925 (Allgemeines Verwaltungsverfahrensgesetz - AVG), last consolidated text was published in Bundesgesetzblatt für die Republik Österreich no. 51/1991.

31 KIJOWSKI, D.R. Austria. In KMIECIAK Z. (ed.). Postępowanie administracyjne w Europie. Warsaw : Wolters Kluwer, 2010, p. 64.

32 Law no. 71 of 29 July 1967 on Administrative Procedure, Zbierka zákonov no. 27/1967, p. 284 with ammendments.

33 Federal Law of 25 May 1976 on Administrative Procedure (Verwaltungsverfahrensgesetz, VwVfG), Bundesgesetzblatt I, p. 1253.

34 KRAWCZYK, A. Republika Federalna Niemiec. In KMIECIAK Z. (ed.). Postępowanie administracyjne w Europie, op. cit., p. $331-332$. 
sion about progressive judicialisation of administrative procedure. Hearing mode practice in common law systems is contrasting to this. Preliminary studies indicate the different approach than in continental systems to the trial as a form of hearing before an administrative authority. Namely, it assumes only one party defending its interests and, therefore, is devoid of adversarial element, which assimilates it to the court proceedings.

\subsection{Services conference in Portugal}

The Italian Law on Administrative Procedure has been amended several times. Moreover, in Portugal a new codification has been adopted, departing significantly from a number of structures known from the Act of 1991 and introducing a number of new institutions, an example of which is modeled on Italian solution (processual conference). Due to the short time since the entry into force in April 2015, the local Code of Administrative Procedure has not been previously analyzed outside Portugal. Its characteristic feature is in particular the limitation of the implementation of the services conference to one of its modified forms. The Portuguese legislator in the implementation of Italian experience saw the possibility of streamlining administrative activities and bringing them closer to the citizen. The procedural conferences (conferências procedimentais) are designed to jointly exercise the competences of various organs of the public administration in order to promote efficiency, economy and speed of administrative activity. Conference may be related to a single procedure or to several related procedures, and accordingly should involve a single decision or several joint decisions. Procedural conferences relating to a number of related procedures or to a single complex procedure, where different decisions may be taken by different bodies, may take the form of deliberative conference or coordination conference. Conferência deliberativa is intended to jointly exercise the decision-making powers of the participating bodies through a single act of complex content, replacing the practice by each of them of autonomous administrative acts. Conferência de coordenação is intended for the individual but simultaneous exercise of the competences of the participating bodies, through the practice, by each of them, of autonomous administrative acts. ${ }^{35}$

\section{CONCLUSION}

On this background, findings of Polish doctrine and case law and practices associated with the cooperation of authorities, including the form and the legal nature of "taking position by the cooperating body", the possibility of conducting evidence proceedings before a cooperative body, and the control of acts of cooperation, can be compare to the services conference. One of the assumptions of the paper is the possibility of recognition of the services conference as a kind of a resultant of proceedings in a form of hearing, and the mode of cooperation between the administrative bodies. Services conference may be treated as an effective tool, mainly as an attempt to deal with the needs

35 For detailed informations see especially SÉRVULO CORREIA, J.M. Da Conferência Procedimental and SERRÃO, T. A Conferência Procedimental no Código do Procedimento Administrativo: primeira aproximação. In O Novo Código do Procedimento Administrativo, Centro de Estudos Judiciários. Lisbon : Centro de Estudos Judiciários, 2016, p. 109 121 and 123 - 147 or SERRÃO, T. A conferência procedimental no novo Código do Procedimento Administrativo: primeira aproximação. In AMADO GOMES, C., NEVES, A.F., SERRÃO, T. (eds.). Comentários ao Novo Código do Procedimento Administrativo, vol. 1. $3^{\text {rd }}$ edition. Lisbon : AAFDL, 2016, p. 655 - 681. 
of tackling the problem of excessive length of proceedings and disadvantages of formalized procedures. On the other hand, we can indicate many barriers and constraints in the implementation of the idea of the services conference and proposals for specific legislative solutions in other European countries. Most important of these are the strict approach to the competences of administrative authorities, strong formalization of the provisions related to their activities and a lack of legal tradition of such a kind of institution.

\section{Bibliography:}

BREWER-CARÍAS, A.R. Los principios del procedimiento administrativo en el Código de procedimiento administrativo y de lo contencioso administrativo de Colombia (Ley 1437 de 2011). In RODRÍGUEZ-ARANA MUŃOZ, J., BELARMINO JAIME, J., SENDÍN GARCÍA, M.Á., MEJÍA, H.A., CARDOZA AYALA, M.Á. (eds.). Congreso Internacional de Derecho Administrativo. X Foro Iberoamericano de Derecho Administrativo El Salvador 2011. El Salvador : San Salvador, 2011. ISBN 978-99923-885-7-0.

COLL COSTA, J. Principios de las relaciones interadministrativas. In RECUERDA GIRELA, M.Á. (ed.). Régimen jurídico del Sector Público y Procedimiento Administrativo Común de las Administraciones Públicas. Pamplona : Aranzadi, 2016. 2018 pages. ISBN 978-84-9135-522-9.

D’ORSOGNA, D. Conferenza di servizi e amministrazione della complessità. Turin : Giappichelli, 2002. 297 pages. ISBN 88-348-2365-6.

KIJOWSKI, D.R. Austria. In KMIECIAK, Z. (ed.). Postępowanie administracyjne w Europie. $2^{\text {nd }}$ edition. Warsaw : Wolters Kluwer, 2010. 444 pages. ISBN 978-83-264-0112-1.

KRAWCZYK, A. Republika Federalna Niemiec. In KMIECIAK, Z. (ed.). Postępowanie administracyjne w Europie. $2^{\text {nd }}$ edition. Warsaw : Wolters Kluwer, 2010. 444 pages. ISBN 978-83-264-0112-1.

MANCILLA I MUNTADA, F. Cooperación entre Administraciones Públicas. In RECUERDA GIRELA, M.Á. (ed.). Régimen jurídico del Sector Público y Procedimiento Administrativo Común de las Administraciones Públicas. Pamplona : Aranzadi, 2016. 2018 pages. ISBN 978-84-9135-522-9.

MUSONE, R. La conferenza di servizi in materia ambientale. Rome : Aracne, 2013. 264 pages. ISBN 978-88-548-6083-4.

RECUERDA GIRELA, M.Á. Órganos de cooperación. In RECUERDA GIRELA, M.Á. (ed.). Régimen jurídico del Sector Público y Procedimiento Administrativo Común de las Administraciones Públicas. Pamplona : Aranzadi, 2016. 2018 pages. ISBN 978-84-9135-522-9.

SERRÃO, T. A Conferência Procedimental no Código do Procedimento Administrativo: primeira aproximação. In O Novo Código do Procedimento Administrativo. Lisbon : Centro de Estudos Judiciários, 2016. 281 pages, ISBN 978-989-8815-37-8.

SERRÃO, T. A conferência procedimental no novo Código do Procedimento Administrativo: primeira aproximação. In AMADO GOMES, C., NEVES, A.F., SERRÃO, T. (eds.). Comentários ao Novo Código do Procedimento Administrativo, vol. 1. $3^{\text {rd }}$ edition. Lisbon : AAFDL, 2016. 826 pages, ISBN 978-972-629-060-5.

SÉRVULO CORREIA, J.M. Da Conferência Procedimental. In O Novo Código do Procedimento Administrativo. Lisbon : Centro de Estudos Judiciários, 2016. 281 pages, ISBN 978-989-8815-37-8.

TALANI, M. La conferenza di servizi. Nuovi ordinamenti giurisprudenziali. Milan : Giuffrè, 2008. 302 pages. ISBN 88-14-13962-8.

\section{Legal acts:}

- Austrian General Administrative Procedure Act of 21 July 1925 (Allgemeines Verwaltungsverfahrensgesetz - AVG), Bundesgesetzblatt für die Republik Österreich no. 51/1991

- Bolivian Law no. 2341 of 23 April 2002 on Administrative Procedure (Ley n 2341 de 23 de abril de 2002, Ley de procedimiento administrativo) 
- Colombian Law no. 1437 of 18 January 2011 (Código de Procedimiento Administrativo y de lo Contencioso Administrativo)

- Costa Rican General Law no. 6227 of 2 May 1978 on Public Administration (Ley General de la Administración Pública), La Gaceta no. 102 of 30 May 1978

- Ecuadorian Decree no. 1634 of 1994 - Statute of Legal Administrative Regime of the Executive (Estatuto del Régimen Jurídico Administrativo de la Función Ejecutiva), Registro Oficial no. 411 of 31 March 1994, second suplement

- German Federal Law of 25 May 1976 on Administrative Procedure (Verwaltungsverfahrensgesetz, VwVfG), Bundesgesetzblatt I p. 1253

- Italian Decreto legislativo no. 152 of 3 April 2006 (Norme in materia ambientale), Gazzetta Ufficiale no. 88 of 14 April 2006, Supplemento Ordinario no. 96

- Italian Law of 7 August 1990, n. 241 - New rules concerning administrative proceedings and the right of access to administrative documents (Nuove norme in materia di procedimento amministrativo e diritto di accesso ai documenti amministrativi), Gazzetta Ufficiale of 18 August 1990, no. 192

- Mexican Federal Law of 14 July 1994 on Administrative Procedure (Ley Federal de Procedimiento Administrativo), Diario Oficial de la Federación of 4 August 1994

- Panamanian Law no. 38 of 31 July 2000, which approved Organic Statute of the Procuraduría de la Administración, regulate administrative procedure and enacted special provisions (Ley que aprueba el Estatuto Orgánico de la Procuraduría de la Administración, regula el Procedimento Administrativo y dicta disposiciones especiales)

- Peruvian Law no. 27444 on General Administrative Procedure (Ley N²7.444 - Ley de Procedimiento Administrativo General), Diario Oficial „El Peruano” of 11 April 2001

- Portuguese Code of Administrative Procedure (Codigo de procedimento administrativo) approved by the DecreeLaw no. 4/2015 of 7 January 2015 (Decreto-Lei $n^{\circ}$ 4/2015, de 7 de janeiro), Diário da República, 1.a série-N.o 4 - 7 de janeiro de 2015

- Slovak Law no. 71 of 29 July 1967 on Administrative Procedure (zákon o správnom konaní (správny poriadok)), Zbierka zákonov no. 27/1967, p. 284

- Spanish Law 40/2015 of 1 October 2015 on the Legal Regime of Public Sector (Ley de Régimen Jurídico del Sector Público), Boletín Oficial del Estado no. 236 of 2 October 2015

- Venezuelan Organic Law on Administrative Procedures of 1 July 1981 (Ley Orgánica de Procedimientos Administrativos), Gaceta Oficial de la República Bolivariana de Venezuela extraordinary no. 2818

\section{Contact information:}

Mgr. Robert Siuciński

rsiucinski@wpia.uni.lodz.pl

Faculty of Law and Administration, University of Lodz

Kopcińskiego 8/12 Street

90-232 Łódź

Poland 